Creative commons User License: CC BY-NC-ND

Abstracted by: EBSCOhost, Electronic Journals Service (EJS),

Google Scholar, Directory of Open Access Journals (DOAJ),

Journal Seek, Scientific Commons,

Food and Agricultural Organization (FAO), CABI and Scopus
Journal of Agricultural Extension

Vol. XX (X) XXXXXX, 20XX

ISSN(e): 24086851; ISSN(Print); 1119944X

http://journal.aesonnigeria.org

http://www.ajol.info/index.php/jae

Email: editorinchief@aesonnigeria.org

\title{
Climate Change Information Needs of Rural Farmers in Enugu State.
}

http://dx.doi.org/10.4314/jae.v20i2.16

Okoro, J. C.

Department of Agricultural Extension, University of Nigeria, Nsukka

Email: okoro.johnchumatex@gmail.com

Phone:08067959031

Agwu, A.E.

Department of Agricultural Extension,

University of Nigeria, Nsukka

Email: agwuekwe@hotmail.com

Phone:08034024251

Anugwa, I.Q.

Department of Agricultural Extension, University of Nigeria, Nsukka

Email: ifeoma.irohibe@unn.edu.ng

Phone:08065435735/ 08117661399

\section{Abstract}

The study assessed the information needs of rural farmers on climate change issues in Enugu State, Nigeria. Using the multistage sampling procedure, 152 respondents were selected and data were collected through the use of a structured interview schedule. Descriptive statistics, factor analysis and multiple linear regression model were used for the analysis. Results of the study showed that all (100.0\%) the respondents were aware of climate change, but lacked adequate knowledge of key climate change issues. The multiple linear regression model revealed a significant influence of years of formal education ( $t=2.020 ; p \leq 0.05$ ), membership of social organizations $(t=2.385 ; p \leq 0.05)$, number of climate change training $(t=-2.438 ; p=p \leq 0.05)$, farm size $(t=2.564 ; p \leq 0.05)$, and access to credit $(t=2.833 ; p \leq 0.05)$ on the respondents' level of knowledge on climate change. The information needs on climate change as perceived by farmers were: use of improved varieties $\sqrt{x}=$ 1.80), occupational diversification $(\bar{x}=1.78)$, and change in timing of farm operations $\left[\begin{array}{l}x \\ =1.76\end{array}\right)$, among others. Poor extension services and infrastructure were the major constraints to effective communication of climate change information. The study recommends the empowerment of extension agents by government to teach farmers climate change adaptation and mitigation measures using languages they can understand and in a participatory manner so as to enable them cope with the challenges of climate change.

Keywords: Adaptation strategy, climate change, information needs, rural farmers, mitigation measures. 
Creative commons User License: CC BY-NC-ND

Abstracted by: EBSCOhost, Electronic Journals Service (EJS),

Google Scholar, Directory of Open Access Journals (DOAJ),

Journal Seek, Scientific Commons,

Food and Agricultural Organization (FAO), CABI and Scopus
Journal of Agricultural Extension

Vol. XX (X) XXXXXX, 20XX

ISSN(e): 24086851; ISSN(Print); 1119944X

http://journal.aesonnigeria.org

http://www.ajol.info/index.php/jae

Email: editorinchief@aesonnigeria.org

\section{Introduction}

Climate change refers to any change in climate overtime, which may be due to natural variability or as a result of human activity (Inter-government Panel on Climate Change, IPCC, 2001). In Nigeria, particular threats are posed to agricultural production arising from changes in rainfall patterns which has resulted to increased desertification in the Sahel region and flooding in the southern part of the country (Spurgeon, Wasilewski, Ikpi \& Foster, 2009). In Enugu state, the most significant impacts of climate change experienced by farmers as identified by Ozor \& Nnaji (2011) are; soil erosion, lack of portable water for human consumption and livestock use, loss of vegetation/pastures, intense weed growth, incidence of pests and diseases distortion and destruction of wildlife ecosystems, decrease in soil fertility and health related issues of climate change which can affect production, drudgery and stress from heat. According to Enete, Madu, Mojekwu, Onyekuru, et al., (2011), the biggest effect of climate change in the State include reduced farm yield and income, drying up of streams/rivers, reduction in storage quality of crops, loss of pastureland/vegetation and destruction of wildlife ecosystem. They noted that these effects are likely attributable to the fact that Enugu state has a drier weather; being closer to the North, and hence has inherent insufficient rain water for maximum crop yield.

To effectively adapt to the vagaries of climate change, rural farmers need information on climate change; as information deficit, in itself, is a type of vulnerability as it is easy for the void to be filled with inaccurate and misleading information. Solomon (2002) asserts that information needs, if effectively met, will enable the user (farmer) to make appropriate decisions on any related problem (climate change) facing him or her. While many farmers are already coping with varying climatic conditions, the weather is becoming less predictable, and some of their strategies may no longer work.

Therefore, to a significant degree, the effectiveness with which farmers adapt to climate change depends on how well current information on climate change issues is made available to them. Consequently, it is essential to provide answers to the following research questions: how knowledgeable are rural farmers in Enugu state 
Creative commons User License: CC BY-NC-ND

Abstracted by: EBSCOhost, Electronic Journals Service (EJS),

Google Scholar, Directory of Open Access Journals (DOAJ),

Journal Seek, Scientific Commons,

Food and Agricultural Organization (FAO), CABI and Scopus
Journal of Agricultural Extension

Vol. XX (X) XXXXXX, 20XX

ISSN(e): 24086851; ISSN(Print); 1119944X

http://journal.aesonnigeria.org

http://www.ajol.info/index.php/jae

Email: editorinchief@aesonnigeria.org

on climate change issues? What information do they need on climate change? What factors militate against the effective communication of information on climate change? Again, what are the possible strategies for improving information dissemination to rural farmers on climate change issues?

Specifically, the study was designed to:

1. assess the knowledge level of rural farmers on agriculture-related climate change issues;

2. identify farmers' sources of information on climate change

3. identify types of climate change information needed by the farmers;

4. identify factors militating against the effective communication of climate change information; and

5. ascertain perceived strategies for improving information dissemination on climate change issues to rural farmers.

\section{Hypothesis}

The null hypothesis for the study was:

1. The socio economic and institutional characteristics of rural farmers do not have any significant influence on farmer's knowledge level on climate change issues.

\section{Methodology}

The study was carried out in Enugu state located between latitude 6.5 (60 30'0N) and a longitude of 7.5 (70 30'0E); (http://en.wikipedia.org/wiki/Enugustate). The state occupies an area of about $8,022,950 \mathrm{Km}^{2}$ (Ezike, 1998) and has a population of about 3,257,278 persons (National Population Commission, NPC, 2006). The state has 17 political Local Government Areas (LGA) and is divided into six (6) agricultural zones namely: Agbani, Awgu, Enugu, Enugu-Ezike, Udi and Nsukka. All rural farmers in the State constituted the population for the study. Multi-stage sampling procedure was used in selecting respondents for the study. In the first stage, four agricultural zones were randomly selected out of the six zones in the State. In the second stage, two blocks each were randomly selected out of the eight blocks in 
Creative commons User License: CC BY-NC-ND

Abstracted by: EBSCOhost, Electronic Journals Service (EJS),

Google Scholar, Directory of Open Access Journals (DOAJ),

Journal Seek, Scientific Commons,

Food and Agricultural Organization (FAO), CABI and Scopus
Journal of Agricultural Extension

Vol. XX (X) XXXXXX, 20XX

ISSN(e): 24086851; ISSN(Print); 1119944X

http://journal.aesonnigeria.org

http://www.ajol.info/index.php/jae

Email: editorinchief@aesonnigeria.org

each zone, giving a total number of eight blocks. In the third stage, three circles were randomly selected out of the eight circles in each block giving a total of six circles per zone. In each circle, seven farmers were purposively selected on the basis of farming experience. Thus, the total number of one hundred and sixty eight (168) farmers was the proposed sample size for the study. However, only one hundred and fifty-two (152) copies of the interview schedule (representing $90.5 \%$ of the distributed instrument) were correctly answered and used for analysis.

In order to assess the knowledge level of the respondents on climate change, they were asked to indicate either yes' or 'no' against the options listed that are the possible causes, effects, mitigations and adaptation strategies. Based on their correct responses to the 36 questions measuring their knowledge level, knowledge scores were used to categorize the respondents thus: 1-12 low knowledge, 13-24 moderate knowledge and 25-36 high knowledge. Farmers were also asked to indicate their sources of information on climate change and a list of possible sources were provided for them to thick either 'yes' or 'no'. To ascertain the type of climate change information they need (objective 3), a 'yes' or 'no' option was provided on the causes, effects, mitigation and adaptation strategies. Similarly, the farmers were asked to indicate the extent to which they needed information on climate change causes, effects, mitigation and adaptation on a three point Likert-type scale of 'highly needed', 'needed', and 'not needed' with response options of 2, 1 and 0 , respectively. The cut-off mean was 1 .

Factors militating against effective communication of climate change information were ascertained (objective 4) using exploratory factor analysis. Exploratory factor analysis was employed in grouping the constraint variables into major constraint factors. However, only variable with loading of 0.4 and above $\{(10 \%$ overlapping variance, Comrey (1962)\} was used in naming the factors. Multiple regression analysis was used to determine the influence of selected socio-economic characteristics of the respondents on their knowledge level of climate change. The regression equation that was used was in the form of:

$Y=\alpha+\beta_{1} X_{1}+\beta_{2} X_{2}+\beta_{3} X_{3} \ldots \beta_{12} X_{12}+U$ 
Creative commons User License: CC BY-NC-ND

Abstracted by: EBSCOhost, Electronic Journals Service (EJS),

Google Scholar, Directory of Open Access Journals (DOAJ),

Journal Seek, Scientific Commons,

Food and Agricultural Organization (FAO), CABI and Scopus
Journal of Agricultural Extension

Vol. XX (X) XXXXXX, 20XX

ISSN(e): 24086851; ISSN(Print); 1119944X

http://journal.aesonnigeria.org

http://www.ajol.info/index.php/jae

Email: editorinchief@aesonnigeria.org

Where: $Y=$ knowledge scores (index) on climate change issues (actual number scored by each respondent on the knowledge score used)

$\alpha=$ constant term

$\beta_{1-} \beta_{12}=$ regression coefficients

$X_{1}=\operatorname{sex}\left(\right.$ male $=1$, female $=2$ ); $X_{2}=$ age (years); $X_{3}=$ married (married $=1$, not married $=0$ ); $X_{4}=$ educational level (number of years spent in formal education); $X_{5}=$ household size (actual number of people living in the household); $\mathrm{X}_{6}=$ religion (Christianity =1, African Traditional Religion $=0$ ); $X_{7}=$ extension visit (yes $=1$, no =0); $\mathrm{X}_{8}=$ access to institutional credit (yes $=1, \mathrm{no}_{0}$ ) $) ; \mathrm{X}_{9}=$ major occupation (farming $=1$, not farming $=0) ; X_{10}=$ member of social/religious group (member $=1$, non-member $=0) ; X_{11}=$ training on climate change (yes=1, no $\left.=2\right) ; X_{12}=$ farm size (ha); $U=$ error term

\section{Results and Discussion}

\section{Knowledge level of rural farmers on climate change issues}

Figure 1 shows that the majority $(58.6 \%)$ of the respondents had moderate knowledge on climate change issues, while $41.4 \%$ had low knowledge. This implies that the farmers are not so knowledgeable about climate change despite the long years of farming experiences and hence are in dire need of sensitization on climate change especially as regards farming. Sarkar \& Padaria, (2010) found out that low level of knowledge retarded the adaptation potential of the community and make them more vulnerable towards climate change. In other words, the higher the level of familiarity with an activity, the higher the level of risk tolerance exhibited.

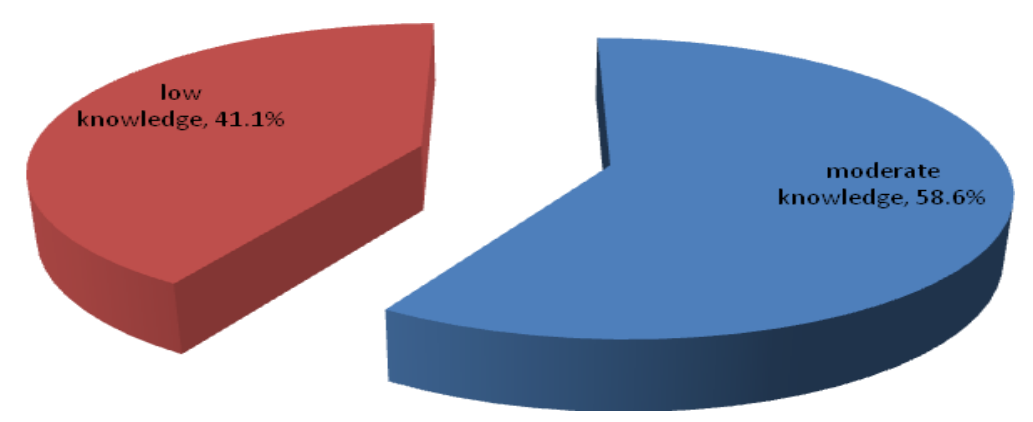

Figure 1: Farmers level of knowledge on climate change 
Creative commons User License: CC BY-NC-ND

Abstracted by: EBSCOhost, Electronic Journals Service (EJS),

Google Scholar, Directory of Open Access Journals (DOAJ),

Journal Seek, Scientific Commons,

Food and Agricultural Organization (FAO), CABI and Scopus
Journal of Agricultural Extension

Vol. XX (X) XXXXXX, 20XX

ISSN(e): 24086851; ISSN(Print); 1119944X

http://journal.aesonnigeria.org

http://www.ajol.info/index.php/jae

Email: editorinchief@aesonnigeria.org

\section{Farmers' sources of information to climate change}

The major sources of information through which the rural farmers received information on climate change in the study area include: personal observation $(98.1 \%)$, friends $(83.8 \%)$, radio $(57.1 \%)$, and television $(26.6 \%)$ (Figure 2). Only $9.1 \%$ indicated extension as source of information on climate change. The high percentage of farmers relying on personal observation might be due to the observable changes on their farms and environment. Tologbonse, Auta, Bidoli \& Jaliya et. al. (2010) reported that farmers seem to have a thorough knowledge of the effect of climate change through personal experience because their livelihood seems to be seriously threatened. Similarly, friends (fellow farmers) equally discuss and share experiences on climate change. However, it should be of concern that only $9.1 \%$ of the farmers recognized extension agencies as their sources of information on climate change phenomena. This is probably because of poor extension services in the study area. Hence, sustainable development strategies (including options that reduce vulnerability and strengthen climate change adaptive and mitigation capacities) need to be made more consistent with other national development policies through extension agents. Such strategies are more likely to be effective than isolated technological or policy options (Munasinghe, nd). 
Creative commons User License: CC BY-NC-ND

Abstracted by: EBSCOhost, Electronic Journals Service (EJS),

Google Scholar, Directory of Open Access Journals (DOAJ),

Journal Seek, Scientific Commons,

Food and Agricultural Organization (FAO), CABI and Scopus
Journal of Agricultural Extension

Vol. XX (X) XXXXXX, 20XX

ISSN(e): 24086851; ISSN(Print); 1119944X

http://journal.aesonnigeria.org

http://www.ajol.info/index.php/jae

Email: editorinchief@aesonnigeria.org

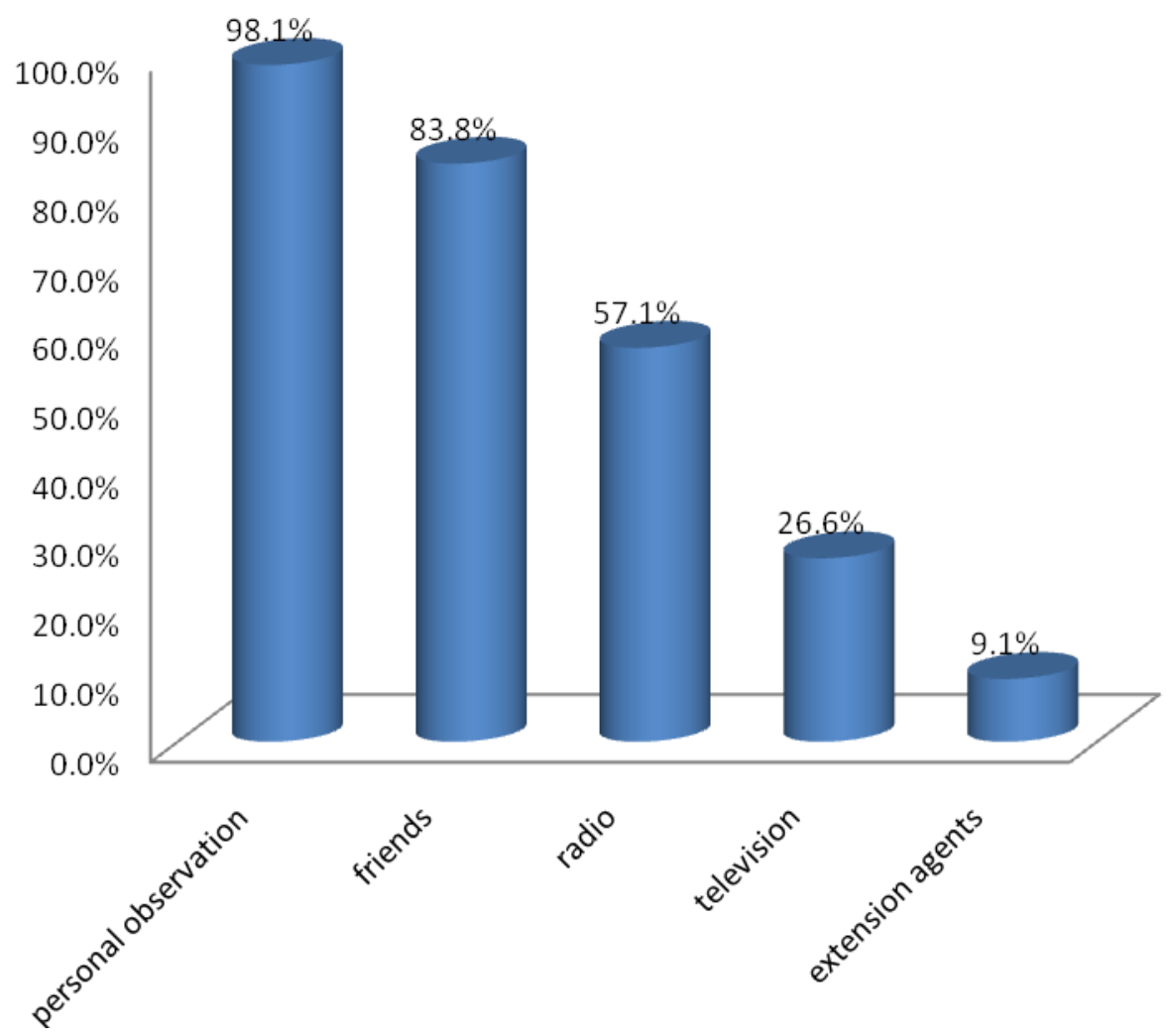

Figure 2: Farmers' sources of climate change information

\section{Climate change information needs of rural farmers}

The majority (91.4\%) of the respondents (Fig 2) indicated that they needed information on adaptation measures, while $58.6 \%, 32.9 \%$ and $11.8 \%$ of them needed information on mitigation, causes and effect of climate change, respectively. Kandlinker \& Risbey (2000) found out that in agriculture, adaptation helps farmers achieve their food, income and livelihood security objectives in the face of changing climatic and socio-economic conditions including climatic variability and extreme weather conditions such as droughts and floods and volatile short term changes in local and large-scale markets. Farmers can reduce the potential damage made by climate change by making tactical response to these changes. 
Creative commons User License: CC BY-NC-ND

Abstracted by: EBSCOhost, Electronic Journals Service (EJS),

Google Scholar, Directory of Open Access Journals (DOAJ),

Journal Seek, Scientific Commons,

Food and Agricultural Organization (FAO), CABI and Scopus
Journal of Agricultural Extension

Vol. XX (X) XXXXXX, 20XX

ISSN(e): 24086851; ISSN(Print); 1119944X

http://journal.aesonnigeria.org

http://www.ajol.info/index.php/jae

Email: editorinchief@aesonnigeria.org
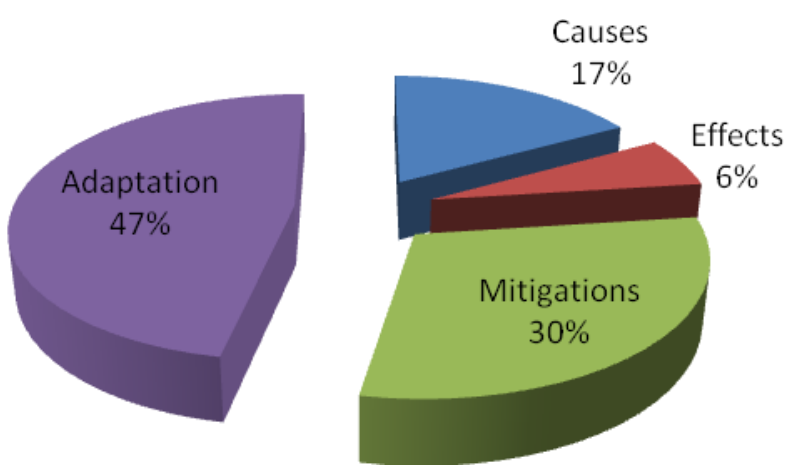

Figure 3: Percentage distribution of respondents based on areas of climate change information needs.

\section{Areas of information needs on climate change}

Entries on Table 1 indicate that climate change information needs of rural farmers in Enugu state were mostly in the area of mitigation and adaptation strategies. Information on the following mitigation and adaptation strategies are highly needed: use of improved varieties $(\bar{x}=1.80)$, occupation diversification $(\bar{x}=1.78)$, use of weed tolerant varieties and planting of trees $(\bar{x}=1.77)$ each, change in timing of farm operation $(\bar{x}=1.76)$, use of herbicides and use of pesticides $(\bar{x}=1.68)$ each as well as, incorporating residue into the soil $(\bar{x}=1.67)$.

Increasing agricultural productivity requires technological advances in both crop and livestock yields. Selvaraju, Subbiah, Baas, \& Juergens (2006) found out that the main adaptation strategies practiced by small-scale farmers were in the form of modification of agronomic practices and in the choice of crop varieties that tolerate the climate change effects on agriculture. The use of such varieties will enable farmers to diversify and produce profitably even under adverse conditions of climate change. 
Creative commons User License: CC BY-NC-ND

Abstracted by: EBSCOhost, Electronic Journals Service (EJS),

Google Scholar, Directory of Open Access Journals (DOAJ),

Journal Seek, Scientific Commons,

Food and Agricultural Organization (FAO), CABI and Scopus
Journal of Agricultural Extension

Vol. XX (X) XXXXXX, 20XX

ISSN(e): 24086851; ISSN(Print); 1119944X

http://journal.aesonnigeria.org

http://www.ajol.info/index.php/iae

Email: editorinchief@aesonnigeria.org

Table 1: Mean distribution of areas of climate change information need of rural farmers

\begin{tabular}{l}
$\begin{array}{l}\text { S/no Climate change information needs } \\
\text { deviation }\end{array}$ \\
\hline
\end{tabular}

Causes of climate change

Bush burning

$\begin{array}{ll}0.51 & 0.781\end{array}$

Paddy rice production

0.43

0.716

Deforestation

0.50

0.781

Overgrazing

0.48

0.763

Use of automobiles

0.45

0.726

Use of excess chemical

0.46

0.745

Effects of climate change

Increase erosion

0.18

0.507

High mortality of livestock

0.18

0.507

Drying up of river and lakes

0.18

0.490

Loss of pastures

0.17

0.471

Harsh weather conditions

0.18

0.490

Abrupt change in weather condition

0.18

0.507

Poor yield of crops

0.18

0.507

Reduction in soil nutrient

0.18

0.507

Increase in pest

0.19

0.524

Mitigation and adaptation strategies

Irrigation

0.77

0.842

Change in timing of farm operation

$1.76^{*}$

0.575

Occupational diversification

$1.78^{*}$

0.539

Herbicide use

$1.68^{*}$

0.580

Use of weed tolerant varieties

$1.77^{\star}$

0.558

Change of enterprise

1.48

0.780

Use of pesticide

$1.68^{*}$

0.593

Use of improve/resistant crop \& animal 1.80*

0.532 varieties

Planting of trees

$1.77^{*}$

0.546

Incorporation of residue into the soil instead

$1.67^{*}$

0.607 of burning

\section{* Major information needs}

${ }^{*}$ cut-off point

Factors militating against effective communication of climate change information

Results on Table 2 represent the factor analysis of perceived factors militating against the effective communication of climate change information to rural farmers. The factors were named based on the item loadings. Factors 1, 2, 3, and 4 were named infrastructural/comprehension problem, technical problem, poor source- 
Creative commons User License: CC BY-NC-ND

Abstracted by: EBSCOhost, Electronic Journals Service (EJS),

Google Scholar, Directory of Open Access Journals (DOAJ),

Journal Seek, Scientific Commons,

Food and Agricultural Organization (FAO), CABI and Scopus
Journal of Agricultural Extension

Vol. XX (X) XXXXXX, 20XX

ISSN(e): 24086851; ISSN(Print); 1119944X

http://journal.aesonnigeria.org

http://www.ajol.info/index.php/jae

Email: editorinchief@aesonnigeria.org

audience relationship problem and extension ineffectiveness, respectively. Factors that loaded under infrastructural/comprehension problem were: abstraction of climate change information $(0.687)$, too many information at a time $(0.658)$, poverty $(0.817)$ and illiteracy/ignorance (0.722), among others. The fact that many rural farmers are illiterates coupled with ignorance/inadequate knowledge of climate change effects makes the rural farmer highly vulnerable to the vagaries of climate change. Anselm \& Taofeeq (2010) reported that most of the problems encountered by farmers in adaptation to climate change are associated with poverty. Mustapha, Undiandeye \& Gwary (2012) also reported that poor and hungry farmers would naturally divert their limited farm income towards the basic necessities like feeding and medication rather than spending on climate change adaptation measures.

Technical problems (factor 2) include: lack of communication facilities (0.634), poor access to timely information (0.589), unfavourable environment during climate change communication (0.648) and complexity of climate change information (0.543). Most climate change terminologies are complex to understand by rural farmers who lack basic formal education. Ozor, Madukwe, Enete \& Amaechina, (2012) pointed out that poor understanding of the concept of global climate change, is limited because the terminologies are poorly understood and there is no standard translation of what climate change means in local languages. Variables that loaded under poor source-audience relationship include: lack of participatory approach (0.640) and poor communication skill (0.796). Effective communication can take place when there is mutual participation in the communication process and the ability of the communicator to have communication skills. Farmers learn more when varieties of teaching methods are employed in information dissemination. Building Communication Opportunities (BCO) Alliance (2009) opined that communication should not just be sharing information, but should be a process that is interactive and participative where there should be exchange of listening and talking.

Factors that loaded under agricultural extension ineffectiveness were: poor communication linkage between scientists and farmers (0.722), lack of proper enlightenment (0.678), and poor use of local dialect in translation and 
Creative commons User License: CC BY-NC-ND

Abstracted by: EBSCOhost, Electronic Journals Service (EJS), Google Scholar, Directory of Open Access Journals (DOAJ), Journal Seek, Scientific Commons,

Food and Agricultural Organization (FAO), CABI and Scopus
Journal of Agricultural Extension

Vol. XX (X) XXXXXX, 20XX

ISSN(e): 24086851; ISSN(Print); 1119944X

http://journal.aesonnigeria.org

http://www.ajol.info/index.php/jae

Email: editorinchief@aesonnigeria.org

communication of climate change information and jargon to rural farmers $(0.611)$. Agricultural extension ineffectiveness is a serious threat to effective communication of climate change information to rural farmers since farmers' ability to adapt to climate change vagaries is dependent on the amount of information received. Ozor et. al. (2010) observed that the major challenges to adaptation by farmers in Southern Nigeria were mainly lack of climate change information and extension services, poor infrastructural development among others.

Table 2: Perceived factors militating against the effective communication of climate change information

\begin{tabular}{|c|c|c|c|c|}
\hline Constraints & $\begin{array}{l}\text { Factor } \\
1\end{array}$ & $\begin{array}{l}\text { Factor } \\
2\end{array}$ & $\begin{array}{l}\text { Factor } \\
3\end{array}$ & $\begin{array}{l}\text { Factor } \\
4\end{array}$ \\
\hline Lack of participatory approach of communication & 0.013 & -0.121 & 0.640 & 0.005 \\
\hline $\begin{array}{l}\text { Poor communication skills of climate change } \\
\text { communicator }\end{array}$ & 0.012 & 0.100 & 0.796 & 0.056 \\
\hline $\begin{array}{l}\text { Lack of trust of climate change information } \\
\text { source }\end{array}$ & -0.095 & 0.476 & 0.530 & -0.032 \\
\hline Lack communication facilities & 0.016 & 0.634 & 0.326 & -0.277 \\
\hline omplexity of climate change information & 0.237 & 0.543 & 0.183 & -0.178 \\
\hline bstraction of climate change information & 0.687 & 0.319 & -0.024 & -0.081 \\
\hline oor access to timely information & 0.214 & 0.589 & 0.077 & 0.206 \\
\hline Poor communication linkage & -0.095 & 0.165 & -0.128 & 0.722 \\
\hline $\begin{array}{l}\text { Unfavourable environment during climate change } \\
\text { communication }\end{array}$ & 0.211 & 0.648 & -0.252 & 0.081 \\
\hline Too many information at a time. & 0.658 & 0.3 & & -0.101 \\
\hline Lack of proper enlightenment & 0.024 & -0.036 & 12 & 0.678 \\
\hline Use of wrong channel of communication & 0.315 & 0.587 & -0.250 & 0.108 \\
\hline Illiteracy/ignorance & 0.722 & 0.005 & 0.151 & -0.019 \\
\hline Helplessness and resignation to fate & 0.333 & 0.504 & -0.009 & 0.020 \\
\hline Poverty & 0.817 & 0.059 & -0.035 & 0.059 \\
\hline Bad road network & 0.757 & 0.294 & -0.117 & 0.138 \\
\hline Poor electricity & 0.750 & 0.231 & -0.020 & 0.135 \\
\hline Poor use of local dialect & 0.191 & -0.116 & 0.304 & 0.611 \\
\hline
\end{tabular}

Factor 1 = infrastructural /comprehension problem; Factor 2 = technical problem; Factor $\mathbf{3}$ = poor source-audience relationship; Factor $\mathbf{4}$ =extension ineffectiveness Extraction Method: Principal Component Analysis.

Rotation Method: Varimax with Kaiser Normalization. 
Creative commons User License: CC BY-NC-ND

Abstracted by: EBSCOhost, Electronic Journals Service (EJS),

Google Scholar, Directory of Open Access Journals (DOAJ),

Journal Seek, Scientific Commons,

Food and Agricultural Organization (FAO), CABI and Scopus
Journal of Agricultural Extension

Vol. XX (X) XXXXXX, 20XX

ISSN(e): 24086851; ISSN(Print); 1119944X

http://journal.aesonnigeria.org

http://www.ajol.info/index.php/jae

Email: editorinchief@aesonnigeria.org

\section{Perceived possible strategies for improving information dissemination on climate change among rural farmers}

Table 3 indicates the perceived strategies that can be used to improve information dissemination on climate change among rural farmers. These include: use of vernacular through mass media to disseminate climate change information $(\bar{x}=$ 2.97), use of participatory approach in communicating climate change information ( $\bar{x}$ $=2.95)$, incorporating the needs, perception and concern of the target audience $(\bar{x}=$ 2.93) and ensuring relevance of information to the target audience ( $\bar{x}=2.93$ ), among others. Most local languages lack terms for many key concepts involved in climate change -including 'climate change' itself. It is therefore the duty of climate change communicators to explain climate change using terms that already exist, using graphic examples of local environmental problems and innovative communication methods (e.g. dramatization) to get the messages across.

Table 3: Mean distribution of farmers' perceived strategies for improving information dissemination on climate change to rural farmers

\begin{tabular}{|c|c|c|}
\hline Strategies* $^{*}$ & Mean & SD \\
\hline $\begin{array}{l}\text { Use of participatory approach in communicating climate change } \\
\text { information }\end{array}$ & $2.95^{*}$ & 0.240 \\
\hline Use of local language (dialect) and folks & $2.89^{*}$ & 0.455 \\
\hline $\begin{array}{l}\text { Incorporating the needs, perception, and concern of target } \\
\text { audience }\end{array}$ & $2.93^{*}$ & 0.275 \\
\hline Ensuring reliability of information & $2.91^{*}$ & 0.334 \\
\hline Ensuring relevance of information to the target audience & $2.93^{*}$ & 0.285 \\
\hline $\begin{array}{l}\text { Use of credible expert who have good knowledge of } \\
\text { Vernacular }\end{array}$ & $2.91^{*}$ & 0.446 \\
\hline Use of audio visual aids & $2.86^{*}$ & 0.448 \\
\hline $\begin{array}{l}\text { The use vernacular through mass media to disseminate } \\
\text { climate change information }\end{array}$ & $2.97^{*}$ & 0.198 \\
\hline $\begin{array}{l}\text { Provision of communication facilities by government to } \\
\text { climate change communicators }\end{array}$ & $2.66^{*}$ & 0.542 \\
\hline Training of communicators of climate change information & $2.83^{*}$ & 0.407 \\
\hline Provision of timely information & $2.86^{*}$ & 0.401 \\
\hline Bridging communication gap between scientists \&farmers & $2.91^{*}$ & 0.325 \\
\hline $\begin{array}{l}\text { Use of service providers to disseminate climate change } \\
\text { information through short message service }\end{array}$ & $1.95^{\star}$ & 1.104 \\
\hline $\begin{array}{l}\text { Use of local and religious leaders to disseminate climate change } \\
\text { information }\end{array}$ & $2.91^{*}$ & 0.325 \\
\hline Strengthening agricultural extension delivery system & $2.77^{*}$ & 0.506 \\
\hline
\end{tabular}


Creative commons User License: CC BY-NC-ND

Abstracted by: EBSCOhost, Electronic Journals Service (EJS),

Google Scholar, Directory of Open Access Journals (DOAJ),

Journal Seek, Scientific Commons,

Food and Agricultural Organization (FAO), CABI and Scopus
Journal of Agricultural Extension

Vol. XX (X) XXXXXX, 20XX

ISSN(e): 24086851; ISSN(Print); 1119944X

http://journal.aesonnigeria.org

http://www.ajol.info/index.php/jae

Email: editorinchief@aesonnigeria.org

\section{*Major strategies}

\section{Regression analysis of the significant influence of socio economic and institutional characteristics of rural farmers on their knowledge level on climate change issues}

Results of the multiple linear regression analysis on influence of socio economic and institutional characteristics on knowledge level of agriculture related climate change issues are presented on Table 4 . The overall regression model was significant $(F=$ 7.189; $\mathrm{p} \leq 0.05$ ) accounting for $36.5 \%$ (adjusted R-squared) of the variance. Variables that had significant influence on knowledge level were years spent in formal education $(t=2.020 ; p=0.045)$, membership of social organization $(t=2.385$; $p=0.019)$, farm size $(t=2.564 ; p=0.011)$, marital status $(t=-2.732 ; p=0.007)$, access to credit $(t=2.833 ; p=0.005)$, and climate change training $(t=3.170 ; p=$ 0.002).

Number of years spent in formal education had a significant positive influence on knowledge level of agriculture related climate change issues. This implies that respondents with higher number of years in formal education have more knowledge of agriculture related climate change issues. Tologbonse et al. (2010) revealed that the higher the level of formal education, the more a farmer is likely to perceive climate change to be a significant problem. Membership of social organization equally had significant positive influence on knowledge level on agriculture related climate change issues. This implies that respondents that belong to more social/religious organizations had more knowledge on agriculture related climate change issues. This could be as a result of exchange of ideas among the members on climate change issues.

Farm size also had significant positive influence on knowledge level on climate change issues. This implies that respondents with large farm size tend to seek for more knowledge on climate change issues because farm size is perhaps associated with greater wealth vis-a-vis more capital and resources; hence the larger the farmer's farm size, the higher the probability of seeking for adaptation measures to constrain climate change effects. Daberkow \& McBride (2003) in Gbetibouo (2009) reported that given the uncertainty and the fixed transaction and information costs 
Creative commons User License: CC BY-NC-ND

Abstracted by: EBSCOhost, Electronic Journals Service (EJS),

Google Scholar, Directory of Open Access Journals (DOAJ),

Journal Seek, Scientific Commons,

Food and Agricultural Organization (FAO), CABI and Scopus
Journal of Agricultural Extension

Vol. XX (X) XXXXXX, 20XX

ISSN(e): 24086851; ISSN(Print); 1119944X

http://journal.aesonnigeria.org

http://www.ajol.info/index.php/jae

Email: editorinchief@aesonnigeria.org

associated with innovation, there may be a critical lower limit on farm size that prevents smaller farms from adopting. As these costs increase, the critical size also increases. It follows that innovations with large fixed transaction and/or information costs are less likely to be adopted by smaller farms. Similarly, Benhin (2006) noted that farm size is a major determinant of speed of adoption of adaptation measures to climate change.

Access to credit also had significant positive influence on knowledge level. Respondents with access to credit have the tendency to seek for more knowledge on agriculture related climate change issues. This is because access to credit tends to increase the respondents' ability to seek for knowledge on agriculture related climate change issues from different sources. Nhemachena (2007) asserted that access to affordable credit increases financial resources of farmers and their ability to meet transaction costs associated with the various adaptation options they might want to take. With more financial and other resources at their disposal, farmers are able to change their management practices in response to changing climatic and other factors and are better able to make use of all the available information they might have on changing conditions both climatic and other socioeconomic factors.

Training on climate change also had significant positive influence on knowledge level of the respondents on agriculture related climate change issues. Respondents who had training on climate change had more knowledge because knowledge increases with training and farmers learn more when trained on what affects their source of livelihood. Nhemachena (2007) asserted that supporting farmers through providing necessary resources such as information and training can significantly help farmers increase and sustain high productivity levels under changing climatic conditions. However, Mustapha, Undiandeye \& Gwary (2012) argued that the continued reduction in government expenditure on agriculture and training (on climate change) has reduced the access of farmers to technology, information, and consequently climate change adaptation. Marital status also had significant negative influence on knowledge level on climate change. This shows that respondents that are single had higher knowledge level on agriculture related climate change issues than the married 
Creative commons User License: CC BY-NC-ND

Abstracted by: EBSCOhost, Electronic Journals Service (EJS),

Google Scholar, Directory of Open Access Journals (DOAJ),

Journal Seek, Scientific Commons,

Food and Agricultural Organization (FAO), CABI and Scopus
Journal of Agricultural Extension

Vol. XX (X) XXXXXX, 20XX

ISSN(e): 24086851; ISSN(Print); 1119944X

http://journal.aesonnigeria.org

http://www.ajol.info/index.php/jae

Email: editorinchief@aesonnigeria.org

respondents. This could be because single respondents tend to have more time for seeking information on climate change than married respondents.

\section{4: Socio economic characteristics and institutional influence on knowledge level on climate change}

\begin{tabular}{|c|c|c|c|c|c|}
\hline \multirow[b]{2}{*}{ Variables } & \multicolumn{2}{|c|}{$\begin{array}{l}\text { Unstandardized } \\
\text { Coefficients }\end{array}$} & \multicolumn{2}{|l|}{$\begin{array}{l}\text { Standardize } \\
\text { d } \\
\text { Coefficients }\end{array}$} & \multirow[b]{2}{*}{ Sig. } \\
\hline & B & Std. Error & Beta & $\mathbf{t}$ & \\
\hline (Constant) & 9.947 & 2.695 & & 3.690 & $.000^{*}$ \\
\hline Sex & -.323 & .734 & -.040 & -.439 & .661 \\
\hline Age & -.002 & .029 & -.005 & -.058 & .954 \\
\hline $\begin{array}{l}\text { Years spent in formal } \\
\text { education }\end{array}$ & .149 & .074 & .194 & 2.020 & $.045^{\star}$ \\
\hline Household size & -.072 & .062 & -.089 & -1.165 & .246 \\
\hline $\begin{array}{l}\text { Membership } \\
\text { organization }\end{array}$ & ff 1.873 & .785 & .225 & 2.385 & $.019^{\star}$ \\
\hline Extension visit & .516 & .388 & .177 & 1.330 & .186 \\
\hline Farm size & .731 & .285 & .196 & 2.564 & $.011^{\star}$ \\
\hline Marital status & -1.680 & .615 & -.196 & -2.732 & $.007^{\star}$ \\
\hline Christianity & .273 & .969 & .023 & .282 & .779 \\
\hline Access to credit & 1.791 & .632 & .229 & 2.833 & $.005^{\star}$ \\
\hline Training on climate change & 5.258 & 1.659 & .368 & 3.170 & $.002^{\star}$ \\
\hline
\end{tabular}

Dependent variable: knowledge level on agriculture related climate change issues R. Square $=0.424 ; R^{2}=0.365 ; F$-value $=7.189 ; p \leq 0.05$

\section{Conclusion and Recommendation}

The study concluded that poor extension services and infrastructure were among the major constraints to effective communication of climate change information and therefore recommended mobilization of extension agents by government for massive enlightenment campaign on agriculture related climate change issues in Enugu state especially on the various communities' market days and through social and religious organizations. There is also need to teach climate change adaptation and mitigation measures to farmers using the language the farmers can understand in a participatory manner (interactive phone in programme) through the mass media using experts on climate change communication. Farmers should be taught the use of improved varieties and changing of timing of farm operation to enable them cope 
Creative commons User License: CC BY-NC-ND

Abstracted by: EBSCOhost, Electronic Journals Service (EJS),

Google Scholar, Directory of Open Access Journals (DOAJ),

Journal Seek, Scientific Commons,

Food and Agricultural Organization (FAO), CABI and Scopus
Journal of Agricultural Extension

Vol. XX (X) XXXXXX, 20XX

ISSN(e): 24086851; ISSN(Print); 1119944X

http://journal.aesonnigeria.org

http://www.ajol.info/index.php/jae

Email: editorinchief@aesonnigeria.org

with the unpredictable nature of climate change. The communication gap between researchers and extension agents need to be bridged. This will help the extension agents to be equipped with the appropriate information that can help the farmers adapt to the adverse effects of climate change.

\section{References}

Anselm, A. E. \& Taofeeq, A. A. (2010). Challenges of agricultural adaptation to climate change in Nigeria: A synthesis from the literature. The Creative Commons Attribution. Facts Reports, 1-11.

Benhin, J.K.A. (2006). Climate change and South African agriculture: impacts and adaptation options. CEEPA Discussion Paper No21.CEEPA, University of Pretoria, South Africa.

Building Communication Opportunities Alliance, BCO, (2009). Planting the knowledge seed and adapting to climate change using ICTs: Concepts, current knowledge and innovative examples. Available online at: https://www.apc.org/en/system/files/BCO ClimateChange.pdf

Comrey, A. L. (1962) The minimum residual method of factor analysis. Psychological Reports, 11: 15-18.

Daberkow S.G. \& McBride W.D. (2003). Farm and operator characteristics affecting the awareness and adoption of precision agriculture technologies in the US. Precision Agriculture, 4(2):163-177.

Enete, A., Ignatius, I.M., Josephat, C.M., Anthony, N.O., Elizabeth, A.O \& Fidelis, E. (2011). Indigenous Agricultural Adaptation to Climate Change: Study of Southeast Nigeria. Research Paper, African Technology Policy Studies Network (ATPS) Nairobi, Kenya.

Ezike, J. O. (1998) Delineation of old and new Enugu State. Bulletin of the Ministry of Works, Lands and Survey, Enugu State.

Gbetibouo, G.A. (2009). Understanding farmers' perceptions and adaptations to climate change and variability: The case of the Limpopo Basin, South Africa. IFPRI Discussion Paper No. 00849. Washington D.C: IFPRI. Available online at: http://www.ifpri.org/sites/default/files/publications/ifpridp00849.pdf

Intergovernmental Panel on Climate Change IPCC (2001). Impact, adaptation and vulnerability. contribution of working group II of the Intergovernmental Panel on Climate Change to the third assessment report of IPCC. Cambridge University Press. London 
Creative commons User License: CC BY-NC-ND

Abstracted by: EBSCOhost, Electronic Journals Service (EJS),

Google Scholar, Directory of Open Access Journals (DOAJ),

Journal Seek, Scientific Commons,

Food and Agricultural Organization (FAO), CABI and Scopus
Journal of Agricultural Extension

Vol. XX (X) XXXXXX, 20XX

ISSN(e): 24086851; ISSN(Print); 1119944X

http://journal.aesonnigeria.org

http://www.ajol.info/index.php/jae

Email: editorinchief@aesonnigeria.org

Kandlinker, M. \& Risbey, J. (2000). Agricultural Impacts of Climate Change: if adaptation is the answer, what is the question? Climatic Change, 45: 529-539.

Mustapha, S.B., Undiandeye, U. C. \& Gwary, M.M. (2012). The role of extension in agricultural adaptation to climate change in the Sahelian Zone of Nigeria. Journal of Environment and Earth Science. 2 (6): 48 - 58.

National Population Commission (NPC) (2006). Official Census Report. Abuja, Nigeria.

Nhemachena, C. (2007). Micro-level analysis of farmers' adaptation to climate change in Southern Africa. IFPRI Discussion Paper, 00714. Washington DC: IFPRI \& CEEPA. Available online at: http://www.ifpri.org/publication/micro-levelanalysis-farmers-adaptation-climate-change-southern-africa

Ozor, N.; Madukwe, M.C.; Onokala P.C.; Enete, A.; Garforth, C.J.; Eboh, E.C.; Ujah, O. \& Amaechina, E. (2010). A framework for agricultural adaptation to climate in Southern Nigeria. A development partnerships in higher education (DelPHE) 326 project executive summary supported by DFID and the British Council, Enugu: African Institute of Applied Economics.

Ozor, N, Madukwe, M.C., Enete, A.A., Amaechina, E.C., Onokala, P., Eboh, E.C., Ujah O., \& Garforth C.J. (2012) A Framework for Agricultural Adaptation to Climate Change in Southern Nigeria. International Journal of Agriculture Sciences, 4 (5): 243-252.

Ozor, N. \& Nnaji, C. (2011). The role of extension in agricultural adaptation to climate change in Enugu State, Nigeria. Journal of Agricultural Extension and Rural Development. 3(3): 42-50.

Sarkar, S. \& Padaria, R. N. (2010).Farmers' awareness and risk perception about climate change in coastal ecosystem of West Bengal. Indian Journal of Extension Education. 10 (2): 32 - 38.

Selvaraju, R., Subbiah, A.R., Baas, S., \& Juergens, I. (2006). Livelihood adaptation to climate variability and change in drought-prone areas of Bangladesh: Developing institutions and options. Food and Agriculture Organization (FAO): Rome. Accessed online on $07 / 08 / 16$ at: ftp://ftp.fao.org/docrep/fao/009/a0820e/a0820e01.pdf

Solomon, P. (2002). Discovering information in context. Annual Review of Information Service and Technology. 36: 229-264. 
Creative commons User License: CC BY-NC-ND

Abstracted by: EBSCOhost, Electronic Journals Service (EJS),

Google Scholar, Directory of Open Access Journals (DOAJ),

Journal Seek, Scientific Commons,

Food and Agricultural Organization (FAO), CABI and Scopus
Journal of Agricultural Extension

Vol. XX (X) XXXXXX, 20XX

ISSN(e): 24086851; ISSN(Print); 1119944X

http://journal.aesonnigeria.org

http://www.ajol.info/index.php/jae

Email: editorinchief@aesonnigeria.org

Spurgeon J., Wasilewski C., Ikpi, A. \& Foster S. (2009). Impact of climate change on Nigeria's economy. Delivering sustainable solutions in a more competitive world. Environmental Resources Management 0082608/DFID/Nigeria Climate Change

Tologbonse, E.B; Auta,S.J; Bidoli, T.D ; Jaliya M.M; Onu, R.O \& Issa F.O (2010), Farmers' perception of the effects of climate change and coping strategies in three agro-ecological zones of Nigeria. Journal of Agricultural Extension, 14 (1): 125. 